Aneta Karwowska

Uniwersytet w Biatymstoku

\title{
O SKUTKACH PRAWNYCH IMMISJI W ŚWIETLE KODEKSU CYWILNEGO I USTAWY Z DNIA 27 KWIETNIA 2001 R. - PRAWO OCHRONY ŚRODOWISKA
}

Przepis art. 144 k.c., jak i art. 323 ustawy z dnia 27 kwietnia 2001 r. - Prawo ochrony środowiska ${ }^{1}$ przewidują określone uprawnienia dla konkretnych podmiotów w przypadku niewłaściwego oddziaływania zakłócającego wykonywanie prawa własności czy powodującego szkodę. Tego rodzaju sytuacje zarówno w doktrynie, jak i orzecznictwie umownie nazywane są immisjami. Oba wskazane przepisy odnoszą się do skutków tzw. immisji pośrednich.

W literaturze zgodnie przyjmuje się, że oddziaływanie na nieruchomość sąsiednią może przybrać postać immisji bezpośredniej lub immisji pośredniej. Przez to pierwsze pojęcie rozumie się bezpośrednią ingerencję w sferę cudzej własności (naruszenie własności). Immisja pośrednia natomiast to ujemne oddziaływanie na nieruchomość sąsiednią, przy czym źródłem tego oddziaływania jest korzystanie przez właściciela z jego nieruchomości. Działania właściciela mogą prowadzić m.in. do wytworzenia ciepła, hałasu, wstrząsów, przykrych zapachów, które utrudniają korzystanie z nieruchomości sąsiednich. Immisjami pośrednimi są także zanieczyszczenie powietrza czy zakłócenia w zakresie odbioru radiowego lub telewizyjnego. Immisje pośrednie dzieli się na immisje pozytywne, które oddziałują wprost na nieruchomości sąsiednie, np. poprzez rozchodzenie się substancji lub energii, oraz negatywne, które polegają na tamowaniu przenikania na nieruchomości sąsiednie, np. światła słonecznego. Wyróżnia się też immisje materialne (gdy następuje przenikanie na nieruchomości sąsiednie cząstek materii, np. pyłów, gazów lub pewnych sił, np. hałasu, wstrząsów) i immisje niematerialne (oddziałujące na psychikę, zwłaszcza poczucie bezpieczeństwa, estetyki, niezależności). ${ }^{2}$

\footnotetext{
Ustawa z dnia 27 kwietnia 2001 r. - Prawo ochrony środowiska (t.j. Dz. U. z 2008 r. Nr 25, poz. 150 ze zm.). E. Skowrońska-Bocian, [w:] K. Pietrzykowski (red.) Z. Banaszczyk, A. Brzozowski, J. Mojak, L. Ogiegło, M. Pazdan, J. Pietrzykowski, W. Popiołek, M. Safjan, E. Skowrońska-Bocian, K. Zaradkiewicz, K. Zawada, Kodeks cywilny. Komentarz do artykułów 1-449[10], Tom I, Warszawa 2011, s. 565-566.
} 
Stosownie do art. 144 k.c., właściciel nieruchomości powinien przy wykonywaniu swego prawa powstrzymać się od działań, które by zakłócały korzystanie z nieruchomości sąsiednich ponad przeciętną miarę, wynikającą ze społeczno-gospodarczego przeznaczenia nieruchomości i stosunków miejscowych.

Cytowany przepis reguluje stosunki sąsiedzkie i zaliczany jest do tzw. prawa sąsiedzkiego (art. 144 k.c. i n.). Bardzo ogólnie definiując tę materię można stwierdzić, że są to normy określające sposób korzystania z nieruchomości sąsiadujących ze sobą i odpowiednio konkretne uprawnienia i obowiązki właścicieli, czy innych osób posiadających tytuł prawny do tych nieruchomości. Przyjmuje się, że sąsiednią jest każda nieruchomość znajdująca się w zasięgu oddziaływania immisji. Nie chodzi tu tylko o bezpośrednie sąsiedztwo, oddziaływanie może dotyczyć również nieruchomości położonych $\mathrm{w}$ dalszej odległości. ${ }^{3}$ Chociaż prawo własności określane jest z zasady jako prawo bezwzględne, erga omnes, to jednak ustawodawca, mając na celu ochronę uzasadnionych indywidualnych interesów wprowadził pewne rozwiązania, które to prawo ograniczają.

Co ważne, wykonywanie prawa własności zawsze powinno być rozpatrywane przez pryzmat art. 140 k.c., czyli w granicach określonych przez ustawy i zasady współżycia społecznego właściciel może, z wyłączeniem innych osób, korzystać z rzeczy zgodnie ze społeczno-gospodarczym przeznaczeniem swego prawa, w szczególności może pobierać pożytki i inne dochody z rzeczy. W tych samych granicach może rozporządzać rzeczą.

Naruszenie określane mianem immisji bezpośrednich, czyli de facto naruszenie prawa własności, może być przekroczeniem normy zawartej w art. 140 k.c. Jak już wspomniano na wstępie, immisje bezpośrednie to bezpośrednia ingerencja w sferę cudzej własności. Przykładowo przerzucenie na nieruchomość sąsiednią nieczystości albo sztuczne skierowanie na nią wód opadowych stanowią bezpośrednie wtargnięcie w sferę cudzej własności. Według przeważających zapatrywań immisje bezpośrednie są zabronione wprost przez art. 140 i nie są objęte hipotezą art. 144 k.c. ${ }^{4}$

Z pewnością art. 144 k.c. stanowi ograniczenie prawa własności i chociaż nakłada obowiązek określonego, powinnego zachowania na właściciela nieruchomości, to przyjmuje się, że obowiązują one również inne podmioty. Jak wskazuje T.A. Filipiak, przepisy tzw. prawa sąsiedzkiego w zasadzie odnoszą się do stosunków między osobami, którymi służy inne niż własność prawo do nieruchomości, zarówno o charakterze rzeczowym, jak i obligacyjnym. ${ }^{5}$

3 J. Ciszewski, komentarz do ks. drugiej tyt. I. dz. II art. 144, [w:] A. Stępień-Sporek, K. Jędrej, G. Kraszewski, J. Knable, B. Ruszkiewicz, P. Nazaruk, G. Sikorki, J. Cieszewski, Kodeks cywilny. Komentarz, wyd. I, Warszawa 2012, publ. LexPolonica.

$4 \quad$ Wyrok Sądu Najwyższego z dnia 15 marca 1968 r., sygn. akt III CRN 41/68, publ. LEX nr 6298.

5 T.A. Filipiak, komentarz do art. 144 Kodeksu cywilnego, [w:] A. Kidyba (red.), K.A. Dadańska, T.A. Filipiak, Kodeks cywilny. Komentarz. Tom II. Własność i inne prawa rzeczowe, Warszawa 2012, publ. LEX nr 134794. 
W wypadku immisji zakłócających korzystanie z nieruchomości może wystąpić zbieg roszczeń. W szczególności zbieg art. 144 k.c. z innymi przepisami kodeksu cywilnego (art. 23 i 24, 435, 439). Kolizja ta musi być rozstrzygana z uwzględnieniem konkretnych okoliczności. ${ }^{6}$

Przykładowo, w postanowieniu z dnia 8 listopada 2012 r. Sąd Najwyższy wskazał, iż rozstrzygając o charakterze dochodzonego roszczenia na podstawie art. 222 $\S 2$ k.c. w zw. z art. 144 k.c., należy mieć na uwadze przede wszystkim stanowisko samego powoda, co do tego do ochrony jakiego rodzaju dóbr - majątkowych, czy niemajątkowych - ma zmierzać wniesione powództwo. ${ }^{7}$

Artykuł 144 k.c. ma zastosowanie nie tylko wtedy, gdy właściciel sąsiedniej nieruchomości doznaje szkody, ale także wtedy, gdy właściciel sąsiedniej nieruchomości przy wykonywaniu swych praw zakłóca korzystanie z nieruchomości sąsiednich ponad przeciętną miarę, wynikającą ze społeczno-gospodarczego przeznaczenia nieruchomości i stosunków miejscowych (np. budowa chodnika betonowego spowodowała nadmierne odpływanie wód spadowych na nieruchomość sąsiada). Natomiast jeżeli zakłócenie wywołuje nadto szkodę, to wówczas ponoszący szkodę może dochodzić odszkodowania, ale na zasadach ogólnych (art. 415 i n. k.c.). Tak też wyrok Sądu Najwyższego z dnia 21 stycznia 1976 r. ${ }^{8}$

Kwestia określenia ,przeciętnej miary” każdorazowo wymaga odniesienia do danego stanu faktycznego. W wyroku Sądu Apelacyjnego w Warszawie z dnia 26 października 2006 r. wyjaśniono, że użycie w art. 144 k.c. pojęcia „przeciętnej miary” zakłada konieczność biernego znoszenia oddziaływania we wszelkiej postaci w określonym stopniu, jeżeli oddziaływanie to nie ma charakteru szykany. Elementem współokreślającym przeciętną miarę jest społeczno-gospodarcze przeznaczenie nieruchomości w powiązaniu ze stosunkami miejscowymi odnoszącymi się zarówno do miejsca, jak i czasu. ${ }^{9}$ Natomiast społeczno-gospodarcze przeznaczenie nieruchomości wynika z jej charakteru. Zasadniczo jest określane w miejscowym planie zagospodarowania przestrzennego (art. 11 ust. 1 ustawy - Prawo zamówień publicznych). Z braku planu, inwestycyjne przeznaczenie gruntu może jeszcze określać decyzja o warunkach zabudowy i zagospodarowania terenu (art. 40 ust. 1 in fine PZP). W końcu zaś należy uwzględnić bieżący sposób korzystania z nieruchomości, zgodny z jej przyrodniczymi właściwościami. ${ }^{10}$

6 J. Ciszewski, komentarz do ks. drugiej tyt. I. dz. II art. 144, [w:] A. Stępień-Sporek, K. Jędrej, G. Kraszewski, J. Knable, B. Ruszkiewicz, P. Nazaruk, G. Sikorki, J. Cieszewski, Kodeks cywilny. Komentarz, wyd. I, Warszawa 2012, publ. LexPolonica.

7 Postanowienie Sądu Najwyższego z dnia 8 listopada 2012 r., sygn. akt IV CSK 400/2012, publ. LexPolonica nr 5143770, www.sn.pl

$8 \quad$ Wyrok Sądu Najwyższego z dnia 21 stycznia 1976 r., sygn. akt III CRN 367/75, publ. LexPolonica nr 309131.

9 Wyrok Sądu Apelacyjnego w Warszawie z dnia 26 października 2006 r., sygn. VI ACa 450/2006, publ. LexPolonica nr 419465.

10 E. Gniewek, Kodeks cywilny. Księga druga. Własność i inne prawa rzeczowe. Komentarz, Zakamycze 2001, publ. LEX nr 73492. 
Konsekwencją przekroczenia dopuszczalnych granic wyznaczonych w art. 144 k.c. i art. 323 Prawa ochrony środowiska jest możliwość wystąpienia przez uprawniony podmiot $\mathrm{z}$ konkretnym roszczeniem.

W przypadku immisji pośrednich, stanowiących naruszenie art. 144 k.c., środkiem ochrony prawnej będzie roszczenie negatoryjne (art. $222 \S 2$ k.c.), przy czym treścią żądania będzie zazwyczaj żądanie zaniechania naruszeń ewentualnie żądanie przywrócenia stanu zgodnego z prawem. W tym miejscu należy jednak zaznaczyć, że stan zgodny z prawem wcale nie oznacza stanu poprzedniego. Jak trafnie wskazuje S. Rudnicki, stan zgodny z prawem może jedynie oznaczać zminimalizowanie immisji do takiego poziomu zakłóceń, że nie będzie ona już więcej przekraczała „przeciętnej miary”. ${ }^{11}$ Nawet decyzja administracyjna określająca sposób korzystania z budynku znajdującego się na nieruchomości, z której pochodzą immisje, nie wyłącza automatycznie możliwości dokonania ocen i ustaleń, czy sposób wynikający z decyzji nie zakłóca korzystania z nieruchomości sąsiednich ponad przeciętną miarę (vide: wyrok Wojewódzkiego Sądu Administracyjnego w Warszawie z dnia 13 stycznia 2011 r.). ${ }^{12}$

Należy mieć jednak na uwadze stanowisko, które zaprezentował m.in. Wojewódzki Sąd Administracyjny w Warszawie w wyroku z dnia 12 listopada 2009 r., w którym stwierdzono, że legalizacja określonych działań w związku z uzyskaniem zezwolenia, o którym mowa w art. 26 ust. 1 ustawy o odpadach, może prowadzić w niektórych przypadkach bezpośrednio do faktycznego zawężenia uprawnień dotyczących ochrony interesów właścicieli sąsiednich nieruchomości w trybie regulacji cywilnoprawnych (w zw. z treścią art. 140 i 144 k.c.). ${ }^{13}$

W sytuacji, kiedy określone działanie właściciela wyrządza szkodę, która wywiera także negatywny wpływ na środowisko naturalne, może dojść do zbiegu art. 144 k.c. z przepisami zawartymi w ustawie z dnia 27 kwietnia 2001 r. - Prawo ochrony środowiska. ${ }^{14}$

Prawo ochrony środowiska $\mathrm{w}$ art. 323 ust. 1 przewiduje, że każdy, komu przez bezprawne oddziaływanie na środowisko bezpośrednio zagraża szkoda lub została mu wyrządzona szkoda, może żądać od podmiotu odpowiedzialnego za to zagrożenie lub naruszenie przywrócenia stanu zgodnego z prawem i podjęcia środków zapobiegawczych, w szczególności przez zamontowanie instalacji lub urządzeń zabezpieczających przed zagrożeniem lub naruszeniem. W razie gdy jest to niemożliwe

11 S. Rudnicki, komentarz do ks. drugiej tyt. I dz. II art. 144, [w:] S. Rudnicki, G. Rudnicki, Komentarz do kodeksu cywilnego. Księga druga. Własność i inne prawa rzeczowe, wydanie X, Warszawa 2011, s. 55.

12 Wyrok Wojewódzkiego Sądu Administracyjnego w Warszawie z dnia 13 stycznia 2011 r., sygn. akt VII SA/Wa 1851/2010, publ. LexPolonica nr 2510740, http://orzeczenia.nsa.gov.pl

13 Wyrok Wojewódzkiego Sądu Administracyjnego w Warszawie z dnia 12 listopada 2009 r., sygn. akt IV SA/Wa 715/2009, publ. LexPolonica nr 2560139, http:/orzeczenia.nsa.gov.pl

14 Kwestię tę precyzyjnie opisuje m.in. W.J. Kutner, Ochrona własności..., op. cit., s. 119 i n.; S. Rudnicki, Komentarz, Warszawa 2007, s. 64 i n. Podaję za: T.A. Filipak, komentarz do art. 144 Kodeksu cywilnego, [w:] A. Kidyba (red.), K.A. Dadańska, T.A. Filipiak, Kodeks cywilny. Komentarz. Tom II. Własność i inne prawa rzeczowe, Warszawa 2012, publ. LEX nr 134794. 
lub nadmiernie utrudnione, może on żądać zaprzestania działalności powodującej to zagrożenie lub naruszenie.

Analizując regulację zawartą $\mathrm{w}$ art. 323 ust. 1 cytowanej ustawy, podobnie jak w art. 144 k.c., należy jednoznacznie stwierdzić, że ustawodawca wprowadził te rozwiązania prawne, aby chronić interesy indywidualne. Co niezmiernie istotne w art. 323 ust. 2 wprowadzono także upoważnienie dla Skarbu Państwa, jednostek samorządu terytorialnego i organizacji ekologicznych, które mogą działać w celu ochrony, jeżeli zagrożenie lub naruszenie dotyczy środowiska jako „dobra wspólnego”.

Możliwość ingerencji podejmowanej z urzędu przez organ ochrony środowiska, w przypadku negatywnego oddziaływania na środowisko przez podmiot korzystający ze środowiska, przewidziana została w art. $375 \mathrm{w}$ zw. z art. 362 ust. 1 Prawa ochrony środowiska. W takiej sytuacji organ może przede wszystkim, w drodze decyzji, nałożyć obowiązek ograniczenia oddziaływania na środowisko i jego zagrożenia bądź też przywrócenia środowiska do stanu właściwego.

Dla zrozumienia istoty art. 323 trzeba odwołać się do zasady prewencji i przezorności, a także do prewencyjnej funkcji prawa w ochronie środowiska. Podstawowym zadaniem współczesnego prawa ochrony środowiska jest zapobieganie negatywnemu oddziaływaniu na środowisko. Komentowany przepis jest uszczegółowieniem zasady prewencji i przezorności. Obejmuje on również elementy restytucyjne..$^{15}$

Środkiem ochrony prawnej w przypadku zaistnienia okoliczności określonych w art. 323 ust. 1 Prawa ochrony środowiska, podmiot poszkodowany może żądać od podmiotu odpowiedzialnego za to zagrożenie lub naruszenie przywrócenia stanu zgodnego z prawem i podjęcia środków zapobiegawczych.

Odnosząc się do kwestii „podmiotu odpowiedzialnego” należy wyjaśnić, iż będzie to nie tylko ten, kto faktycznie wyrządza szkodę, ewentualnie którego działania zagrażają wyrządzeniem szkody, jak również podmiot, który pomimo iż bezpośrednio nie dokonuje określonych czynności faktycznie i prawnie jest odpowiedzialny za szkodę. W literaturze przedmiotu wskazano, iż za szkody w środowisku jest odpowiedzialny ten, kto prowadzi działalność, a także czerpiący z niej korzyści, mimo że bezpośrednio nie oddziałuje w sposób bezprawny na środowisko. ${ }^{16}$ A. Lipieński dodaje, że roszczenie oparte o treść art. 323 ustawy, kieruje się przeciwko temu, komu można przypisać takie bezprawne zachowanie się i niekoniecznie musi on być „podmiotem korzystającym ze środowiska” w rozumieniu art. 3 pkt 20 komentowanej ustawy. ${ }^{17}$

15 B. Rakoszy, komentarz do art. 323, [w:] B. Rakoszy, Z. Bukowski, J. Ciechanowicz-Mclean, Prawo ochrony środowiska, wyd. I, Warszawa 2008, publ. LexPolonica.

16 W. J. Katner, M. Pysiak-Szafnicka, Odpowiedzialność cywilnoprawna w ustawie o ochronie środowiska (uwagi de lege ferenda), Ochrona Środowiska, „Prawo i Polityka” 1996, nr 3.

17 A. Lipieński, Komentarz do art. 323, [w:] W. Skarżyska, M. Bojarski, M. Bar, J. Boć, K. Nowacki, J. Jerzmański, M. Górski, J. Jendrośka (red. nauk.), E. Kaleta-Jagiełło, J. Rotko, T. Tatomir, A. Lipieński, Ustawa - Prawo ochrony środowiska. Komentarz, Warszawa 2001, publ. LexPolonica. 
Podmiotem uprawnionym do wystąpienia z określonym roszczeniem jest każdy, komu przez bezprawne oddziaływanie na środowisko zagraża szkoda lub została mu wyrządzona szkoda. Zatem roszczenie przysługiwało będzie osobom legitymującym się prawem własności, ograniczonymi prawami rzeczowymi, prawem najmu. Będzie ono także przysługiwało osobom legitymującym się posiadaniem i innym tytułem dającym uprawnienia do władania. ${ }^{18}$ J.J. Skoczylas prezentuje również pogląd, zgodnie z którym komentowany artykuł stanowi kompilację norm art. 439 i 435 k.c. i w żadnym wypadku nie wyłącza on zastosowania art. $222 \S 2$ k.c. ${ }^{19}$ Odmienne stanowisko zawarte zostało w wyroku Wojewódzkiego Sądu Apelacyjnego w Olsztynie z dnia 18 listopada 2008 r., który stwierdził, iż ustawodawca dokonał w ustawie wyraźnej systematyzacji zagadnień związanych ze środkami odpowiedzialności cywilnej i administracyjnej, które w sposób wyraźny rozgraniczył. Tak ochrona interesu indywidualnego może być dochodzona w drodze roszczenia cywilnego, o którym mowa w art. 323 ustawy, z drugiej zaś strony wyraźnie uregulowano zagadnienia związane $\mathrm{z}$ prowadzonymi z urzędu postępowaniami w interesie publicznym. W tym stanie rzeczy także wykładnia systemowa prowadzi do jednoznacznego wniosku, iż środki ochrony cywilnoprawnej i administracyjnoprawnej nie mogą być stosowane łącznie w celu ochrony tego samego interesu określonego podmiotu. ${ }^{20}$

Przy ocenie bezprawności oddziaływania należy wziąć pod uwagę treść przepisu art. 325 Prawa ochrony środowiska, stanowiącego, że odpowiedzialności za szkody wyrządzone oddziaływaniem na środowisko nie wyłącza okoliczność, iż działalność będąca przyczyną powstania szkód jest prowadzona na podstawie decyzji i w jej granicach. ${ }^{21}$

Jak wskazano w wyroku Wojewódzkiego Sądu Administracyjnego w Warszawie z dnia 12 lipca 2006 r., w świetle regulacji ustawy - Prawo ochrony środowiska interes indywidualny podmiotów narażonych na określone uciążliwości, na skutek naruszenia wymagań ochrony środowiska, chroniony jest właściwymi roszczeniami, które mogą być dochodzone przed sądami powszechnymi (patrz art. m.in. 323 w tytule VI dziale I ustawy - Prawo ochrony środowiska). Regułą jest natomiast, iż środki administracyjne jako podejmowane w interesie publicznym są stosowane z urzędu, co potwierdza treść art. 375 w tytule VI dziale II ustawy - Prawo ochrony środowiska, jak i m.in. art. 95 ust. 3, art. 108 ust. 3, art. 150 ust. 4 i in. usta-

\footnotetext{
18 J.J. Skoczylas, Odpowiedzialność cywilna na podstawie ustawy - Prawo ochrony środowiska, PS 2003, nr 4, s. 67.

19 Ibidem, s. 68.

20 Wyrok Wojewódzkiego Sądu Administracyjnego w Olsztynie z dnia 18 listopada 2008 r., sygn. akt II S.A./OI 761/08, publ. LEX nr 487996.

21 E. Radziszewski, Komentarz do art. 323, [w:] E. Radziszewski, Prawo ochrony środowiska. Przepisy i komentarz, wyd. I, Warszawa 2003, publ. LexPolonica.
} 
wy. ${ }^{22}$ Podobnie wyrok Wojewódzkiego Sądu Administracyjnego w Warszawie z dnia 11 kwietnia 2007 r. $^{23}$

Przedstawione powyżej regulacje prawne $\mathrm{z}$ pewnością stanowią normy powszechnie obowiązującego prawa, mające na celu uporządkowanie pewnych zasad współżycia społecznego, a także ochronę zarówno interesów indywidualnych, jak i środowiska przed niedozwoloną ingerencją. Z punktu widzenia orzecznictwa z pewnością można stwierdzić, iż często są przedmiotem rozważań, stanowiąc skuteczną metodę walki z naruszeniami, określonymi w przepisach art. 144 k.c. i art. 323 ustawy - Prawo ochrony środowiska.

\section{BIBLIOGRAFIA}

Ciszewski J., Komentarz do ks. drugiej tyt. I. dz. II art. 144, [w:] A. Stępień-Sporek, K. Jędrej, G. Kraszewski, J. Knable, B. Ruszkiewicz, P. Nazaruk, G. Sikorki, J. Cieszewski, Kodeks cywilny. Komentarz, wyd. I, Warszawa 2012, publ. LexPolonica.

Filipiak T.A., Komentarz do art. 144 Kodeksu cywilnego, [w:] A. Kidyba, K.A. Dadańska, T.A. Filipiak (red.), Kodeks cywilny. Komentarz. Tom II. Własność i inne prawa rzeczowe, Warszawa 2012, publ. LEX nr 134794.

Gniewek E., Kodeks cywilny. Księga druga. Własność i inne prawa rzeczowe. Komentarz, Zakamycze 2001, publ. LEX nr 73492.

Katner W.J., Pysiak-Szafnicka M., Odpowiedzialność cywilnoprawna w ustawie o ochronie środowiska (uwagi de lege ferenda), Ochrona Środowiska, „Prawo i Polityka” 1996, nr 3.

Lipieński A., Komentarz do art. 323, [w:] W. Skarżyska, M. Bojarski, M. Bar, J. Boć, K. Nowacki, J. Jerzmański, M. Górski, J. Jendrośka (red.), E. Kaleta-Jagiełło, J. Rotko, T. Tatomir, A. Lipieński, Ustawa - Prawo ochrony środowiska. Komentarz, Warszawa 2001, publ. LexPolonica.

Rudnicki S., Komentarz do ks. drugiej tyt. I dz. II art. 144, [w:] S. Rudnicki, G. Rudnicki, Komentarz do kodeksu cywilnego. Księga druga. Własność i inne prawa rzeczowe, wydanie X, Warszawa 2011.

Rakoszy B., Komentarz do art. 323, [w:] B. Rakoszy, Z. Bukowski, J. Ciechanowicz-Mclean, Prawo ochrony środowiska, wyd. I, Warszawa 2008, publ. LexPolonica.

Radziszewski E., Komentarz do art. 323, [w:] E. Radziszewski, Prawo ochrony środowiska. Przepisy i komentarz, wyd. I, Warszawa 2003, publ. LexPolonica.

Skoczylas J.J., Odpowiedzialność cywilna na podstawie ustawy - Prawo ochrony środowiska, PS 2003, $\mathrm{nr} 4$.

Skowrońska-Bocian E., [w:] K. Pietrzykowski, Z. Banaszczyk, A. Brzozowski, J. Mojak, L. Ogiegło, M. Pazdan, J. Pietrzykowski, W. Popiołek, M. Safjan, E. Skowrońska-Bocian, K. Zaradkiewicz, K. Zawada (red.), Kodeks cywilny. Komentarz do artykułów 1-449[10], Tom I, Warszawa 2011.

22 Wyrok Wojewódzkiego Sądu Administracyjnego w Warszawie z dnia 12 lipca 2006 r., sygn. akt IV SA/Wa 739/2006, publ. LEX nr 243081, LexPolonica nr 1589248, „Gazeta Prawna” 2007, nr 185, s. 22.

23 Wyrok Wojewódzkiego Sądu Administracyjnego w Warszawie z dnia 11 kwietnia 2007 r., sygn. akt IV S.A./Wa 316/07. publ. LEX nr 336985. 


\section{LEGAL CONSEQUENCES OF A NUISANCE IN THE LIGHT OF THE POLISH ACT OF 27 APRIL 2001 - ENVIRONMENTAL LAW AND THE CIVIL CODE}

The Polish legal system has provided regulations prohibiting infringement of the right to property and unlawful impact on the environment. Under the Polish Civil Code, it is called a neighbour law. An impact on the neighbouring property may take the form of nuisance direct or indirect. According to The Polish Civil Code, an owner of immovable property shall in exercise of his right therein refrain from activities which might interfere with the use of adjoining immovable properties and which are in excess of its normal use as depicted by its socio-economic purpose and local conditions.

The Act of 27 April 2001 - Environmental Law provides for liability for an injury or a threat of injury to the environment. Article 323 therein contains a detailed regulation on this issue. The following publication provides an overview of the regulations.

Keywords: indirect nuisance, direct nuisance, damage to the environment, trespass, neighbouring property 